\title{
Lord Hoffmann
}

\section{The Universality of Human Rights}

Judicial Studies Board Annual Lecture

19 March 2009

1. The claim of human rights to be universal can no doubt be traced back to mediaeval natural law theory and beyond, but for practical purposes I can begin in 1776 with the Declaration of Independence drafted by Thomas Jefferson: "we hold these truths to be self-evident, that all men are created equal, that they are endowed by their Creator with certain unalienable rights, that among these are life, liberty and the pursuit of happiness." In 1789 the Declaration of the Rights of Man and of the Citizen proclaimed by the French National Assembly had 17 articles and said that the "imprescriptible rights of man" were "liberty, property, security and resistance to oppression".

2. The Declaration was redrafted by the National Convention in 1793. As the monarchy had been abolished and replaced by the Republic One and Indivisible, "resistance to oppression" was no longer needed and was replaced by "equality". The Declaration included provisions now very familiar in human rights instruments, such as article 7, "The right to express one's thoughts and opinions by means of the press or in any other manner, the right to assemble peaceably, the free pursuit of religion, cannot be forbidden", article 19, "no one can be deprived of the least portion of his property without his consent, unless a legally established public necessity requires it, and upon condition of a just and prior compensation" and article 22, "Education is needed by all. Society 
ought to favour with all its power the advancement of public reason and put education at the door of every citizen." It also contained provisions of more local and contemporary interest, such as several articles justifying the execution of the King earlier in the year and article 27, "Let any person who may usurp the sovereignty be instantly put to death by free men", which proved useful in 1794, when the principal authors of the Declaration were guillotined.

3. Jeremy Bentham wrote a stinging attack on the French Declaration in an essay which he called "The Anarchical Fallacies". He criticised it on three main grounds. The first was that the rights it declared were all against the government but there was no provision for enforcement in a court. The only remedy proposed was insurrection, which he described as an invitation to permanent anarchy: hence the name of the essay. Bentham thought the notion of unenforceable rights ridiculous; the famous phrase "nonsense on stilts" comes from this essay.

4. Secondly, Bentham criticised the presumption of the authors in declaring the rights of man instead of the rights of Frenchmen. It gave the French, he said,

"The pleasure, the sort of titillation so exquisite to the nerve of vanity in a French heart--the satisfaction...of teaching grandmothers to suck eggs. Hark! ye citizens of the other side of the water! Can you tell us what rights you have belonging to you? No, that you can't. It's we that understand rights: not our own only, but yours into the bargain; while you poor simple souls know nothing about the matter."

5. As I shall explain later, I think that Bentham was making a very important point about the essentially national character of rights, embedded in a 
national legal system, but in this case his brilliant invective was aimed at an inappropriate target. The French Declaration, as he pointed out in his first criticism, was not intended to be a legal document or create legal rights. It was a statement of moral and political philosophy. Call it a constitutional mission statement. It used the term rights in a different, non-legal, sense. The purpose of the Declaration was clearly stated in its preamble:

"In order that all citizens, being able to compare unceasingly the acts of the government with the aim of every social institution, may never allow themselves to be oppressed and debased by tyranny, and in order that the people may always have before their eyes the foundations of their liberty and their welfare, the magistrate the rule of his duties, the legislator the purpose of his commission."

6. Thus the purpose of the declaration was to provide a standard against which the government and its officials could be made subject to political criticism and to state the grounds upon which a government could be justifiably overthrown.

7. Bentham's third criticism was that even if the Declaration had been legally enforceable, the various rights were stated in terms so abstract as to be meaningless. The practical application of the rights needed trade-offs between individual rights and the general public interest, sometimes between one individual right and another. The Declaration gave no guidance on these points, established no hierarchy of rights, contained no concessions to the realities of government, law and order. Such decisions involve the application of practical and political judgment. "Observe" said Bentham - 
"how nice, and incapable of being described beforehand by any particular marks, are the lines which mark the limits of right and wrong in this behalf--which separate the useful from the pernicious, the prudent course from the imprudent--how dependent upon the temper of the times, upon the events and circumstances of the day."

8. Bentham praised the traditional reluctance of the English Parliament to enact abstract propositions. Everyone in Europe agreed that in England was a free country; that there was, for example, freedom of speech although there was no law which expressly said so. To say that we enjoyed freedom of speech was a descriptive generalisation of particular English laws which limited the circumstances in which publications were actionable or the government could suppress them. It was these specific laws which gave people their rights. "It is in England, rather than in France", said Bentham -

"that the discovery of the rights of man ought naturally to have taken its rise: it is we--we English, that have the better right to it...Our right to this precious discovery, such as it is, of the rights of man, must, I repeat it, have been prior to that of the French. It has been seen how peculiarly rich we are in materials for making it. Right, the substantive right, is the child of law: from real laws come real rights; but from imaginary laws, from laws of nature, fancied and invented by poets, rhetoricians, and dealers in moral and intellectual poisons, come imaginary rights."

9. Again, I think that Bentham was making an important point but was wrong to apply it to a mission statement like the French Declaration. An aspirational and political document can be expressed in abstract and unqualified terms. It is intended to set an agenda for political debate, to provide a standard for political criticism of institutions and officials. For that purpose, it did not matter that there might be differences of opinion over whether, for 
example, some law was or was not consistent with freedom of speech. On the contrary, the Declaration performed the valuable function of telling politicians, officials, lawyers and the people at large that these were important questions which needed to be considered and debated.

10. Bentham's criticism about enacting abstract propositions might have been more appropriately directed to the United States, where the Bill of Rights Amendments of 1790 had done just that. That was very definitely not a mission statement but a list of legally binding principles. The first Amendment, for example, said "Congress shall make no law respecting an establishment of religion, or prohibiting the free exercise thereof; or abridging the freedom of speech, or of the press, or the right of the people peaceably to assemble, and to petition the Government for a redress of grievances". "Congress shall make no law"; that was a constitutional limitation on its powers which would have to be interpreted by the courts. And in Marbury $v$ Madison $^{1}$ the Supreme Court decided that it was required to review Acts of Congress for compatibility with the Constitution.

11. The United States Supreme Court was, I think, the first judicial body required to give practical effect to the abstract terms of a human rights instrument; to act as mediators between the high generalities of the constitutional text and the messy detail of their application to concrete problems. Did the words "equal treatment" in the $14^{\text {th }}$ amendment mean that a local education authority could or should provide buses to carry children across

\footnotetext{
${ }^{1}$ (1803) 1 Cranch 137.
} 
town to ensure that schools were not in practice racially segregated ${ }^{2}$ Did the words of the Fifth Amendment, "no person shall be compelled in a criminal case to give evidence against himself' mean that a policeman had to warn a suspect that he need not say anything and tell him that he was entitled to a lawyer at state expense ${ }^{3}$ The need to decide questions like these gave the Supreme Court a power to influence American society unequalled by any other judicial tribunal in the world. Until the 1930 s, this power seems to have been exercised with considerable restraint. Under Franklin Roosevelt, however, the court's economic and social conservatism brought it into conflict with both Congress and the administration. After the War, the court sometimes felt obliged to use the Constitution to initiate necessary reforms with which the legislature, through political stalemate or inertia, was unable to grapple. Brown $v$ Board of Education of Topeka ${ }^{4}$ initiated a change in the country's attitude to racial segregation. Miranda $v$ Arizona $^{5}$ reined in the lawlessness of the police. The Court's decisions on abortion, religious observances, hate speech, capital punishment and a range of similar social issues placed it in the forefront of public controversy.

12. Jefferson would have regarded at least some of the provisions of the Bill of Rights amendments as universals in the sense of being founded upon moral imperatives which were applicable to all human beings, truths about the human condition which, as he said in the Declaration of Independence, were self-

\footnotetext{
${ }^{2}$ Swann v. Charlotte-Mecklenburg Board of Education 402 U.S. 1 (1971)

${ }^{3}$ Miranda v Arizona (1966) 384 US 436.

${ }^{4}$ (1954) 347 US 483.

5 .(1966) 384 US 436.
} 
evident. But the concrete application of these provisions by the Supreme Court, their realisation in practice by bussing school children and making policeman read suspects their Miranda rights, were not at all universal. They were founded on the day-to-day realities of American life, federalism, the American doctrine of the separation of powers, American political culture and legal tradition. They remain so to this day.

13. The result is that in many cases the abstractions of the American Bill of Rights are interpreted differently from very similar abstractions in the legal systems of other countries. For example, most human rights instruments contain protection of privacy from unlawful searches and seizures. But only in the United States is this interpreted as making inadmissible any evidence, however compelling, obtained by an unlawful search. ${ }^{6}$ Equally, most human rights instruments protect the freedom of the press, like the First Amendment, and the right to a fair trial, like the Sixth Amendment. But the United States strikes its own balance between these two rights. In the United Kingdom, for example, a publication which creates a substantial risk of prejudice to the course of justice in legal proceedings is a contempt of court. ${ }^{7}$ In the United States, as one saw in the O J Simpson trial, it is extremely rare for a judge to be able to restrain any publication about the case. ${ }^{8}$

14. It was not to be expected that the United States Supreme Court would be able to exercise these remarkable powers to universal satisfaction. The passions aroused by the questions it has had to decide are too strong. But the Court has

\footnotetext{
${ }^{6}$ Wong Sun v. United States, 371 U.S. 471, 83 S. Ct. 407, 9 L. Ed. 2d 441 (1963).

${ }^{7}$ Contempt of Court Act 1981, sections 1 and 2.
} 
retained more or less universal respect. There are several reasons. One is the generally high quality of the judges. Another is their knowledge of American society. But the third, which I would emphasise, is that they are an American court, created by the Constitution, appointed by the President, confirmed by the Senate, an essential and historic part of the community which they serve. They have a special constitutional legitimacy for the citizens of the United States.

15. The important lesson which one draws from the American experience, and in particular the way in which the U.S. Bill of Rights has been interpreted in the United States, is that, at the level of abstraction, human rights may be universal. The Bill of Rights, like the French Declaration, reflects a certain moral and political philosophy of man as an independent self-reliant agent as well as a member of society. The two instruments have a great deal in common. At the level of application, however, the messy detail of concrete problems, the human rights which these abstractions have generated are national. Their application requires trade-offs and compromises, exercises of judgment which can be made only in the context of a given society and its legal system. Decisions such as whether the abstract concept of equal treatment requires in its practical application the bussing of school children is one which can be made only in a specific social context. Likewise, the decision as to whether the concept of a fair trial requires a complete ban on the admissibility of a statement made without a Miranda warning, or of evidence obtained by an unlawful search or seizure, can be made only in relation to a particular system of trial and with an appreciation of such matters as the prevalent police culture.

${ }^{8}$ Nebraska Press Assn. v. Stuart, 427 U.S. 539 (1976) 
16.

17. Until the Second World War the United States was, I think, the only significant country with a constitution containing an abstract statement of what would now be called human rights which was enforceable by the courts. I say, what would now be called human rights, because I do not think that until the War, this was a common form of constitutional usage. American judges, as in England, spoke rather of liberty and freedom, the freedom of the individual from interference by the state. Indeed, it was this narrow concept of American self-reliance and self-sufficiency which formed the philosophical basis of the decisions to strike down some of the New Deal social legislation.

18. After the Second World War, the terms of discourse changed. It was now of human rights and of universalism. Roosevelt's State of the Union address in 1941, before the United States entered the War, listed the four freedoms he wanted to exist, not merely in the United States, but everywhere in the world. The first two, freedom of speech and religion, came from the First Amendment. But the third, freedom from want, was a new social right born of the Depression and the fourth, freedom from fear, looked forward to disarmament, collective security and the United Nations.

19. In 1946 Eleanor Roosevelt presided over the United Nations Committee which drafted the Universal Declaration of Human Rights. Like the French Declaration of 1789 , this was a mission statement, not intended to have legal effect in either international or domestic law. Its preamble stated its purpose in terms very similar to that of 1789 . The Declaration was to be - 
a common standard of achievement for all peoples and all nations, to the end that every individual and every organ of Society, keeping this Declaration constantly in mind, shall strive by teaching and education to promote respect for those rights and freedoms and by progressive measures, national and international, to secure their universal and effective recognition and observance."

20. The French Declaration's claim to universality rested upon purely philosophical foundations. The claim of the UN Declaration had the additional support of its being adopted by the General Assembly, with 48 countries voting in favour and 8 abstentions. More recently, its claims to universality have been disputed. Some Asian and African writers and politicians say that their countries were not represented at the United Nations in 1948 and that the Declaration reflects a peculiarly Western liberal tradition. Islamists say that it is a Judeo-Christian document. I am not concerned with these disputes. It is also fair to say that the Declaration contains some rather dubious human rights, such as the right in article 24 to periodic holidays with pay, which is no doubt socially desirable but difficult to regard as a fundamental human right. However, in a purely aspirational document, this does not matter.

21. It mattered rather more when the Universal Declaration was used as a model for the International Covenant on Civil and Political Rights and the European Convention for the Protection of Human Rights and Fundamental Freedoms. I do not make any criticism of the drafting of the Convention. It seems to me a perfectly serviceable abstract statement of the rights which individuals in a civilised society should enjoy. At the national level, the precise wording of the document is not important, because the values which it expresses have deep roots in our national history and culture. What matters is 
how these familiar rights are interpreted in relation to other rights and the business of government. It therefore seems to me perfectly acceptable to adopt the text of the Convention as a United Kingdom constitutional instrument. That is what we did in the Human Rights Act 1998.

22. What concerns me, however, is the mechanism adopted by the Convention for the application of these abstractions to concrete problems. It provided that there should be an international court in Strasbourg to decide whether in any particular case a Member State had complied with its duty to accord the Convention rights everyone within its jurisdiction. Individuals in a Member State could petition the court with a complaint that their rights had been violated.

23. If one accepts, as I have so far argued, that human rights are universal in abstraction but national in application, it is not easy to see how in principle an international court was going to perform this function of deciding individual cases, still less why the Strasbourg court was thought a suitable body to do so. At the time that the Convention was drafted and negotiated, the example of the United States was there for everyone to see. Even supposing that the Convention had reproduced the precise language of the American Bill of Rights, one could hardly imagine a court of judges from various nationalities telling the people of the United States that their courts had applied their constitution incorrectly, or telling the people of other nations that, for example, the balance between freedom of the press and a fair trial should be struck in the same way as in the United States. The examples I have given do not represent 
some special American eccentricity but only the inevitable differences in the ways in which different countries, each equally dedicated to the abstract values of human rights, will apply those concepts and strike balances between them.

24. The fact that the 10 original Member States of the Council of Europe subscribed to a statement of human rights in the same terms did not mean that they had agreed to uniformity of the application of those abstract rights in each of their countries, still less in the 47 states which now belong. The situation is quite different from that of the European Economic Community, in which the Member States agreed that it was in their economic interest to have uniform laws on particular matters which were specified as being within European competence. On such matters, the European institutions, including the Court of Justice in Luxembourg, were given a mandate to unify the laws of Europe. The Strasbourg court, on the other hand, has no mandate to unify the laws of Europe on the many subjects which may arguably touch upon human rights. Because, for example, there is a human right to a fair trial, it does not follow that all the countries of the Council of Europe must have the same trial procedure. Criminal procedures in different countries may differ widely without any of them being unfair. Likewise, the application of many human rights in a concrete case, the trade-offs which must be made between individual rights and effective government, or between the rights of one individual and another, will frequently vary from country to country, depending upon the local circumstances and legal tradition. 
25. It is a remarkable fact that during the drafting and negotiation of the European Convention, which is chronicled in detail by Professor Brian Simpson, ${ }^{9}$ no one seems to have drawn attention to this basic flaw in the concept of having an international court of human rights to deal with the concrete application of those rights in different countries. The Working Party of officials from departments concerned in the negotiations noted in January $1951^{10}$ :

"The original purpose of the Council of Europe Convention on Human Rights was to enable public attention to be drawn to any revival of totalitarian methods of government and to provide a forum in which the appropriate action could be discussed and decided."

26. In other words, a regional European mission statement like the Universal Declaration. The Attorney-General, Sir Hartley Shawcross KC, was sceptical of its value even as a mission statement:

"I have never attached great practical importance to the proposed Covenant on Human Rights and do not myself think (as some do) that its existence would act as a kind of barrier against the encroachments of totalitarian restrictions. It seems to me, however, that some of the drafting objections are more theoretical than real. No other country engages, or need engage, in any over nice and meticulous comparison of its own municipal laws against its treaty obligations...The most that can be sought in connection with such political manifestos as in effect are constituted by these Conventions on Human Rights is that in substance and principle, if not in every detail, our practice protects the rights laid down."

\footnotetext{
${ }_{9}^{9}$ AWB Simpson, Human Rights and the End of Empire (OUP 2001).

${ }^{10}$ Simpson, op cit, p. 777.
} 
27. The Strasbourg court has to a limited extent recognised the fact that while human rights are universal at the level of abstraction, they are national at the level of application. It has done so by the doctrine of the 'margin of appreciation', an unfortunate Gallicism by which Member States are allowed a certain latitude to differ in their application of the same abstract right. Clearly, that is a step in the right direction. But there is no consistency in the application of this doctrine and for reasons to which I shall return in a moment, I do not think that there is a proper understanding of the principle upon which it should be based. In practice, the Court has not taken the doctrine of the margin of appreciation nearly far enough. It has been unable to resist the temptation to aggrandise its jurisdiction and to impose uniform rules on Member States. It considers itself the equivalent of the Supreme Court of the United States, laying down a federal law of Europe.

28. I could give many examples, but I shall confine myself to three and keep off the Strasbourg court's jurisprudence on anti-terrorism laws and deportation, on which there is a case under consideration in the House of Lords at the moment. First, the court's enthusiasm for the right to silence. Lord Mustill once described this as an expression which arouses strong but unfocussed feelings. ${ }^{11}$ He deconstructed it into six separate immunities, each resting upon a different policy and subject to various exceptions. Lord Templeman said of one of them, the right to refuse to answer questions if the answer might tend to incriminate, that it affords protection for the guilty and is unnecessary to safeguard the innocent. Such a right can be justified, he said, only on the 
grounds that it discourages ill-treatment of a suspect and the production of dubious confessions. ${ }^{12}$ In cases in which neither of these dangers is present, English law has for many years had a number of statutory exceptions. Sometimes they take the form of providing that the answer may not be used in criminal proceedings (for example, section 31 of the Theft Act 1968) and sometimes they do not. In particular, as far back as the time of Lord Eldon, the power to examine bankrupts about their property has been construed as excluding the privilege. ${ }^{13}$ In 1856 the Court for Crown Cases Reserved held that the answers were admissible in criminal proceedings against the bankrupt. ${ }^{14}$ Since the Bankruptcy Act 1883 it has been the invariable practice for statutes dealing with such examinations to provide that the notes of the examination may be used in evidence against the deponent. These rules were extended to the examination of company directors in a winding-up and by section 434 of the Companies Act 1985 to a company investigation by inspectors appointed by the Secretary of State. There is in such cases no question of ill-treatment of a suspect. The examination is conducted in a civilised manner and the witness is entitled to have his lawyer present. The danger of a false confession is remote. Indeed, the main value of such statements in subsequent criminal proceedings is that they sometimes contain the witness's first thoughts at variance with his later story.

\footnotetext{
${ }^{11} R v$ Director of Serious Fraud Office, ex parte Smith [1993] AC 1, 30-32.

${ }^{12}$ Istel Ltd $v$ Tully [1993] AC 45, 53.

${ }^{13}$ Ex parte Cossens (1805) Buck. 410

${ }^{14} R \vee$ Scott (1856) Dears \& Bell 47.
} 
29. That was the background to the case of Mr Saunders, the chief executive of Guinness plc, who was convicted of conspiracy, false accounting and theft in connection with a take-over bid for Distillers plc, on evidence which included a transcript of what he had said to inspectors appointed by the Secretary of State to investigate the affair. In 1996 the Strasbourg Court held that he had been denied the human right to a fair trial guaranteed by article 6 . It was acknowledged that article 6 did not mention the right to silence, but the Court said in sweeping fashion that "the right to silence and the right not to incriminate oneself are generally recognised international standards which lie at the heart of the notion of a fair procedure under article 6." There was no analysis of the right to silence in English law such as Lord Mustill had undertaken three years earlier. There was no discussion of the 200 year old history of similar provisions in English bankruptcy and company law. The Irish judge, who presumably took his researches no further than to see that the Act currently in force had been passed in 1985, said that it was "a post-Convention constitutional departure from the common law." The usual boilerplate about protection of the accused against improper pressures was reproduced, but there was no explanation of why it was improper, let alone a gross violation of human rights, for Mr Saunders to have to tell the inspectors about his actions during the take-over. The court said that the privilege applied to "all types of criminal offences without distinction from the most simple to the most complex." The public interest could not be invoked to justify "such a marked departure from one of the basic principles of a fair procedure." One would 
imagine from the language of the Court that the inspectors had used thumb screws to obtain the information.

30. The crude terms in which the Strasbourg court held the privilege applicable encouraged other applicants. Most recently, in O'Halloran and Francis $v$ United Kingdom the owner of a car complained that his privilege had been violated because he had been required, on pain of a fine, to say who had been driving his car when it was photographed speeding. One might have thought such a reductio ad absurdum of the Saunders principle would have been thrown out as manifestly ill-founded. On the strength of the Saunders decision, someone had tried the same argument before a Scottish court and then as a devolution issue before the Privy Council. Lord Bingham had disposed of the point politely but firmly. In Strasbourg, the case was solemnly argued before the Grand Chamber. And although the application was rejected, there were two dissenting opinions. In order that you may appreciate the type of reasoning employed in Strasbourg, I cannot resist reading a passage from one of the dissents:

"I understand the reasoning behind the departure from the basic principles of a fair trial in the case of speed violations: namely, that such offences represent hundreds of thousands if not millions of cases, and that the State is unable to ensure that in each of this vast number of cases all the procedural guarantees have been complied with. I repeat: I understand this line of reasoning but I do not accept it. In my opinion, if there are so many breaches of a prohibition, it clearly means that something is wrong with the prohibition. It means that the prohibition does not reflect a pressing social need, given that so many people choose to breach it even under threat of a criminal prosecution. And if this is the case, maybe the time has come to review speed limits and set limits that would more correctly reflect peoples' needs...It is 
difficult for me to accept that hundreds of thousands of speeding motorists are wrong and only the government is right."

31. Next, the Strasbourg court's enthusiasm for the hearsay rule. In England, there has for many years been debate about its merits in both civil and criminal proceedings. It has been generally thought irrational and an obstacle to justice. In civil proceedings, tentative steps to restrict its application started in 1938 and its abolition was finally accomplished by the Civil Evidence Act 1995. In criminal proceedings, the rule was substantially abolished, after a Law Commission report, by the Criminal Justice Act 2003, but subject to various safeguards to ensure a fair trial. In the recent case of Al-Khawaja and Tahery $v$ UK (20 January 2009) the Strasbourg court has discovered that the hearsay rule is a fundamental human right. Dr Al-Khawaja was a doctor charged with indecent assault on two of his patients. One of them, after making a statement to the police, committed suicide. The judge admitted her statement under the provisions of the 2003 Act but warned the jury that they had not seen the complainant or heard her cross-examined. But her story was supported by strong similar fact evidence, not only from the other complainant but from two other witnesses who had had similar experiences. The jury convicted unanimously and the doctor was given a custodial sentence. The Court of Appeal said that the overall case against the appellant was very strong and they were wholly unpersuaded that the verdicts were unsafe. The Strasbourg court said that there had been a violation of the fair trial provision of article 6 . In their opinion, in any case in which a conviction is based "solely or to a decisive 
degree" on a statement by a person whom the accused has had no opportunity to examine, he has not had a fair trial. It is not clear to me whether the accused gave evidence to contradict the statement but for the purposes of the Strasbourg rule that appears not to matter. This was a case after the Human Rights Act 1998 had come into force and in which the Court of Appeal expressly considered whether the procedure was compatible with article 6 . It is quite extraordinary that on a question which had received so much consideration in the Law Commission and Parliament, the Strasbourg court should have taken it upon themselves to say that they were wrong.

32. The last example is about night flights at Heathrow, which sounds about as far from human rights as you could get. In 1993 the government, after a good deal of research and consultation, introduced a change in the regulations about landings after 4:30 am. There were objections from residents in the area and a challenge by judicial review on the grounds of the inadequacy of the consultation, which was finally dismissed by the Court of Appeal. The Secretary of State, in deciding to authorise the new scheme, had to decide whether the general economic interest of the country outweighed the obvious inconvenience to the residents. That was an essentially political decision which his government had been elected to make. In 2001, in Hatton $v$ United Kingdom $^{15}$, the Strasbourg court decided by a majority of 5 to 2 that there had been a violation of the rights of the local residents to privacy and family life and by a majority of 6 to 1 that there was a breach of article 13 because judicial

\footnotetext{
${ }^{15}$ (2003) 37 EHRR 611
} 
review was an inadequate remedy for anyone who complained that such rights had been violated. The residents were of course free to sell their houses and move somewhere else and in some cases the prices they had paid originally must have reflected their proximity to the Heathrow flight path, but the Strasbourg Court nevertheless said that -

"in the absence of a prior specific and complete study with the aim of finding the least onerous solution as regards human rights, it is not possible to agree that in weighing the interferences against the economic interest of the country - which itself had not been quantified - the Government struck the right balance in setting up the 1993 Scheme."

33. The judges of the Chamber in Strasbourg therefore considered that it was their function under the Convention was to decide whether the elected Government of the United Kingdom had struck the right balance concerning flights at Heathrow. The Government succeeded in obtaining a reference to the Grand Chamber, where the decision on article 8 was reversed by 12 votes to 5 but the Court nevertheless held by 16 votes to 1 (that being Sir Brian Kerr, the UK ad hoc judge) that judicial review had been an inadequate remedy.

34. I regard all three of these cases, and many others which I could mention if there was time, as examples of what Bentham called teaching grandmothers to suck eggs. In Brown $v$ Stott ${ }^{16}$, Lord Bingham made some wise remarks about the interpretation of an international treaty like the European Convention:

"In interpreting the Convention, as any other treaty, it is generally to be assumed that the parties have included the terms which they wished to include and on which they were able to agree, omitting other terms which they did not wish to include or on which they

${ }^{16}$ [2003] 1 AC 681, 703. 
were not able to agree. Thus particular regard must be had and reliance placed on the express terms of the Convention, which define the rights and freedoms which the contracting parties have undertaken to secure. This does not mean that nothing can be implied into the Convention. The language of the Convention is for the most part so general that some implication of terms is necessary, and the case law of the European court shows that the court has been willing to imply terms into the Convention when it was judged necessary or plainly right to do so. But the process of implication is one to be carried out with caution, if the risk is to be averted that the contracting parties may, by judicial interpretation, become bound by obligations which they did not expressly accept and might not have been willing to accept."

35. Contrast this with the dissenting opinion in Hatton's case of Judge

Costa, who is now the President of the Strasbourg court:

"It is true that the original text of the Convention does not yet disclose an awareness of the need for the protection of environmental human rights ${ }^{2}$. In the 1950s, the universal need for environmental protection was not yet apparent...[But] as the Court has often underlined: "The Convention is a living instrument, to be interpreted in the light of present-day conditions"...This "evolutive" interpretation by the Commission and the Court of various Convention requirements has generally been "progressive", in the sense that they have gradually extended and raised the level of protection afforded to the rights and freedoms guaranteed by the Convention to develop the "European public order". In the field of environmental human rights, which was practically unknown in 1950, the Commission and the Court have increasingly taken the view that Article 8 embraces the right to a healthy environment, and therefore to protection against pollution and nuisances caused by harmful chemicals, offensive smells, agents which precipitate respiratory ailments, noise and so on."

36. The proposition that the Convention is a "living instrument" is the banner under which the Strasbourg court has assumed power to legislate what they consider to be required by "European public order". I would entirely accept that the practical expression of concepts employed in a treaty or 
constitutional document may change. To take a common example, the practical application of the concept of a cruel punishment may not be the same today as it was even 50 years ago. But that does not entitle a judicial body to introduce wholly new concepts, such as the protection of the environment, into an international treaty which makes no mention of them, simply because it would be more in accordance with the spirit of the times. ${ }^{17}$ It cannot be right that the balance we in this country strike between freedom of the press and privacy should be decided by a Slovenian judge saying of a decision of the German Constitutional Court -

"I believe that the courts have to some extent and under American influence made a fetish of the freedom of the press...It is time that the pendulum swung back to a different kind of balance between what is private and secluded and what is public and unshielded." ${ }^{18}$

37. What grandeur, Bentham would have said. What legislative power the judicial representative of Slovenia can wield from his chambers in Strasbourg. Out with this pernicious American influence. What do their courts or Founding Fathers know of human rights? It is we in Strasbourg who decree the European public order. Let the balance be struck differently, I say, and all the courts of Europe must jump to attention.

38. These thoughts prompt another reason why an international court such as Strasbourg should be particularly cautious in extending its reach in this way. That is because, unlike the Supreme Court of the United States or the Supreme

\footnotetext{
${ }^{17}$ See Birmingham City Council v Oakley [2001] 1 AC617, 631-632.

18 Judge Zupančič concurring in Von Hannover v Germany (24 June 2004).
} 
Courts of other countries performing a similar role, it lacks constitutional legitimacy. The court now has 47 judges, one for each member state of the Council of Europe. One country, one judge; so that Liechtenstein, San Marino, Monaco and Andorra, which have a combined population slightly less than that of the London Borough of Islington, have four judges and Russia, with a population of 140 million, has one judge. The judges are elected by a subCommittee of the Council of Europe's Parliamentary Assembly, which consists of 18 members chaired by a Latvian politician, on which the UK representatives are a Labour politician with a trade union background and no legal qualifications and a Conservative politician who was called to the Bar in 1972 but so far as I know has never practised. They choose from lists of 3 drawn by the governments of the 47 members in a manner which is totally opaque.

39. It is therefore hardly surprising that to the people of the United Kingdom, this judicial body does not enjoy the constitutional legitimacy which the people of the United States accord to their Supreme Court. This is not an expression of populist Euroscepticism. Whatever one may say about the wisdom or even correctness of decisions of the Court of Justice in Luxembourg, no one can criticise their legitimacy in laying down uniform rules for the European Union in those areas which fall within the scope of the Treaty. But the Convention does not give the Strasbourg court equivalent legitimacy. As the case law shows, there is virtually no aspect of our legal system, from land law to social security to torts to consumer contracts, which is not arguably 
touched at some point by human rights. But we have not surrendered our sovereignty over all these matters. We remain an independent nation with its own legal system, evolved over centuries of constitutional struggle and pragmatic change. I do not suggest belief that the United Kingdom's legal system is perfect but I do argue that detailed decisions about how it could be improved should be made in London, either by our democratic institutions or by judicial bodies which, like the Supreme Court of the United States, are integral with our own society and respected as such.

40. In saying this, I do not wish to minimise the importance of aspirational international statements of abstract human rights such as the Universal Declaration or the efforts of the international human rights movement which has gained such widespread support throughout the world over the past 60 years. The Universal Declaration provides a recognised standard against which governments may be criticised and are effectively criticised by other governments and international organisations. For these political activities, the Universal Declaration and the human rights movement provides powerful support. But the fraudulent Mr Saunders, the sleepless Mr Hatton and the sexually predatory Dr Al-Khawaja are unlikely to have had their causes taken up by Human Rights Watch or Amnesty International. The practices of torture, extra-judicial killings and detention without trial with which such organisations are concerned do not require a bench of 47 judges with 200 or so assistants to decide that they are violations of human rights. Indeed, it could be said to trivialise and discredit the grand ideals of international human rights that cases 
like the examples I have discussed should provide the material for an international law of human rights.

41. One might, I suppose, have an international tribunal which declared in general terms that the practices of a Member State were plainly not in accordance with human rights, declaring, for example, that Italy does not have an efficient court system or Russia does not have a fair one. But these are political rather than judicial statements. One does not need a court to pronounce upon them.

42. I say nothing about the enforcement of human rights by courts of universal jurisdiction, such as the International Criminal Court at The Hague. There is much that can be said for and against such a jurisdiction, which is altogether different from that of the Strasbourg court. The International Criminal Court is not concerned with the finer points of Serbian criminal procedure, or whether its limitation period for the recovery of land are too long, or whether there is a human right to sue the police for negligence and other such matters on which the Strasbourg court has assumed jurisdiction to lay down the law of England.

43. I return finally to the doctrine of the margin of appreciation, which I said the Strasbourg court had not taken nearly far enough, and as to which they had not properly stated the principle upon which it should be based. The court treats the margin as a matter of concession to Member States on the ground that they are likely to know more about local conditions than the judges in Strasbourg. In other words, they assume that in principle they are competent to decide any 
question about the law of a Member State which is arguably touched by human rights but sometimes abstain from exercising this vast jurisdiction on the ground that it is something which the local judges are better equipped to do. What I think they should recognise is that we are concerned with a matter of constitutional competence, that is, whether they have the right to intervene in matters on which Member States of the Council of Europe have not surrendered their sovereign powers. Even if the Strasbourg judges were omniscient, knowing the true interests of the people of the United Kingdom better than we do ourselves, it would still be constitutionally inappropriate for decisions of the kind which I have been discussing to be made by a foreign court.

44. What is to be done? We got into this position by lack of foresight. Can we get out of it? Let me clear about what the problem is. First, as I said earlier, I have no difficulty about the text of the European Convention or its adoption as part of United Kingdom law in the Human Rights Act 1998. It was largely drafted in London, intended to reflect common law understandings of human rights and, interpreted by United Kingdom courts as the American Bill of Rights is interpreted by American courts, would be a perfectly serviceable British bill of rights. There is nothing to be gained by fiddling with the language. Secondly, I think it would be valuable for the Council of Europe to continue to perform the functions originally envisaged in 1950, that is, drawing attention to violations of human rights in Member States and providing a forum in which they can be discussed. Thirdly, I have no objection to the text of the 
Convention being used as a standard against which a country's compliance with human rights can be measured for the purposes of such political criticism. Fourthly, I would accept, indeed applaud, the use of this instrument at the political level as a benchmark for compliance with human rights by members of the European Union. The problem is the Court; and the right of individual petition, which enables the Court to intervene in the details and nuances of the domestic laws of Member States. Not only that: the right of individual petition, which was optional until 1998 but is now compulsory, has produced a flood of such petitions which is overwhelming the Court. On 1 November 2008 there was a backlog of 100,000 applications pending, of which $60 \%$ were from 5 countries: Russia, Turkey, Romania, Ukraine and Italy. As against that, in 2008 24,200 petitions were declared inadmissible and 1,205 judgments were given. So the backlog represents about 4 years work and is growing. As the figures show, a very large proportion of petitions were inadmissible, but the court has no summary mechanism for dealing with hopeless cases. Every petition properly filled in must go before a committee of 3 judges and then, if admissible, before a committee of 5. In 2004 the Member States signed a $14^{\text {th }}$ Protocol which would enable a single judge to deal with admissibility cases and a committee of three to give final judgments in cases which are "already the subject of well-established case-law of the Court." This is presumably so that the Court can husband its resources for larger committees to deal with cases which are not the subject of well-established case law of the court. But these 
cases, where the point is reasonably arguable both ways, are likely to be the very cases in which the court should not be intervening at all.

45. The $14^{\text {th }}$ Protocol has not come into force because Russia has refused to ratify it. I am not altogether surprised. After all, what have the Russians to gain from increasing the turnover of the Strasbourg court? Unless, however, something is done, the court will drown in its workload. At some time the Member States of the Council of Europe will have to sit down and decide upon its future. When they do, I hope they will give more serious thought than they did in 1950 to what exactly it is supposed to do. 